HW -79141

UC -4 , Chemistry (TID-4500, 23rd Ed.)

\title{
A THERMOBALANCE FOR STUDYING THE CHLORINATION OF PLUTONIUM DIOXIDE WITH PHOSGENE \\ By
}

R. J. Sorenson

Quality Control

Weapons Manufacturing Operation

Chemical Processing Department

October 1963

FIRST UNRESTRICTED

DISTRIBUTION MADE

\section{HANFORD ATOMIC PRODUCTS OPERATION RICHLAND, WASHINGTON}

Work performed under Contract No. AT $(45-1)-1350$ between the Atomic Energy Commission and General Electric Company

Printed by/for the U. S. Atomic Energy Commission

Printed in USA. Price $\$ 0.50$ Available from the Office of Technical Services Department of Commerce Washington 25, D.C. 


\section{DISCLAIMER}

This report was prepared as an account of work sponsored by an agency of the United States Government. Neither the United States Government nor any agency Thereof, nor any of their employees, makes any warranty, express or implied, or assumes any legal liability or responsibility for the accuracy, completeness, or usefulness of any information, apparatus, product, or process disclosed, or represents that its use would not infringe privately owned rights. Reference herein to any specific commercial product, process, or service by trade name, trademark, manufacturer, or otherwise does not necessarily constitute or imply its endorsement, recommendation, or favoring by the United States Government or any agency thereof. The views and opinions of authors expressed herein do not necessarily state or reflect those of the United States Government or any agency thereof. 


\section{DISCLAIMER}

Portions of this document may be illegible in electronic image products. Images are produced from the best available original document. 


\begin{abstract}
An automatic recording thermobalance for studying the chlorination of plutonium dioxide with phosgene is described. The highly toxic and corrosive nature of these materials imposed restrictions on the construction and operation of the thermobalance.

The instrument operates on the deflection balance principle in which the extension of a precision quartz helix spring is measured by a linear variable differential transformer. Experimental results from the gas-solid reaction between phosgene and plutonium dioxide are discussed.
\end{abstract}




\section{A THERMOBALANCE FOR STUDYING THE CHLORINATION}

OF PLUTONIUM DIOXIDE WITH PHOSGENE

\section{INTRODUCTION}

A process for the preparation of metallic plutonium using a chloride intermediate is being developed at Hanford. $(1,2,3)$ The proposed process would include calcination of plutonium nitrate to $\mathrm{PuO}_{2}$, chlorination of $\mathrm{PuO}_{2}$ to $\mathrm{PuCl}_{3}$, and electrolytic reduction of $\mathrm{PuCl}_{3}$ to the metallic plutonium.

An automatic recording thermobalance was built to study the chlorination of $\mathrm{PuO}_{2}$ with phosgene (carbonyl chloride). The data obtained were used to determine calcination and chlorination conditions which affect the extent of chlorination of $\mathrm{PuO}_{2}$.

The instrument operates on the deflection balance principle in which the extension of a precision quartz helix spring is measured by a linear variable differential transformer. The highly toxic and corrosive nature of these compounds imposed restrictions on the materials of construction and on the operation of the instrument; that is, the toxicity of the alphaemitting plutonium compounds and the toxicity and corrosiveness of phosgene. No commercial instrument that was readily adaptable to these severe conditions could be obtained. Therefore, a thermobalance was constructed and installed in a glove box where plutonium compounds and phosgene were kept under controlled conditions.

$\underline{\text { APPARATUS }}$

The thermobalance operates on the deflection balance principle in which the extension of a precision quartz helix spring is measured by a linear variable differential transformer. Because of the highly toxic nature of plutonium compounds and phosgene, the instrument was installed in a standard $4 \times 6 \times 8 \mathrm{ft}$ Hanford glove box which opened into a fume hood (see Figure 1). The associated electronic equipment was placed outside the glove box. To assure that no phosgene was released to the roomatmosphere*, the

* The maximum permissible concentration for prolonged exposure to phosgene is about 1 ppm in air. 
supply cylinder was kept in the fume hood, and the cylinder, valve, and flow meters were also placed in small ventilated enclosures.

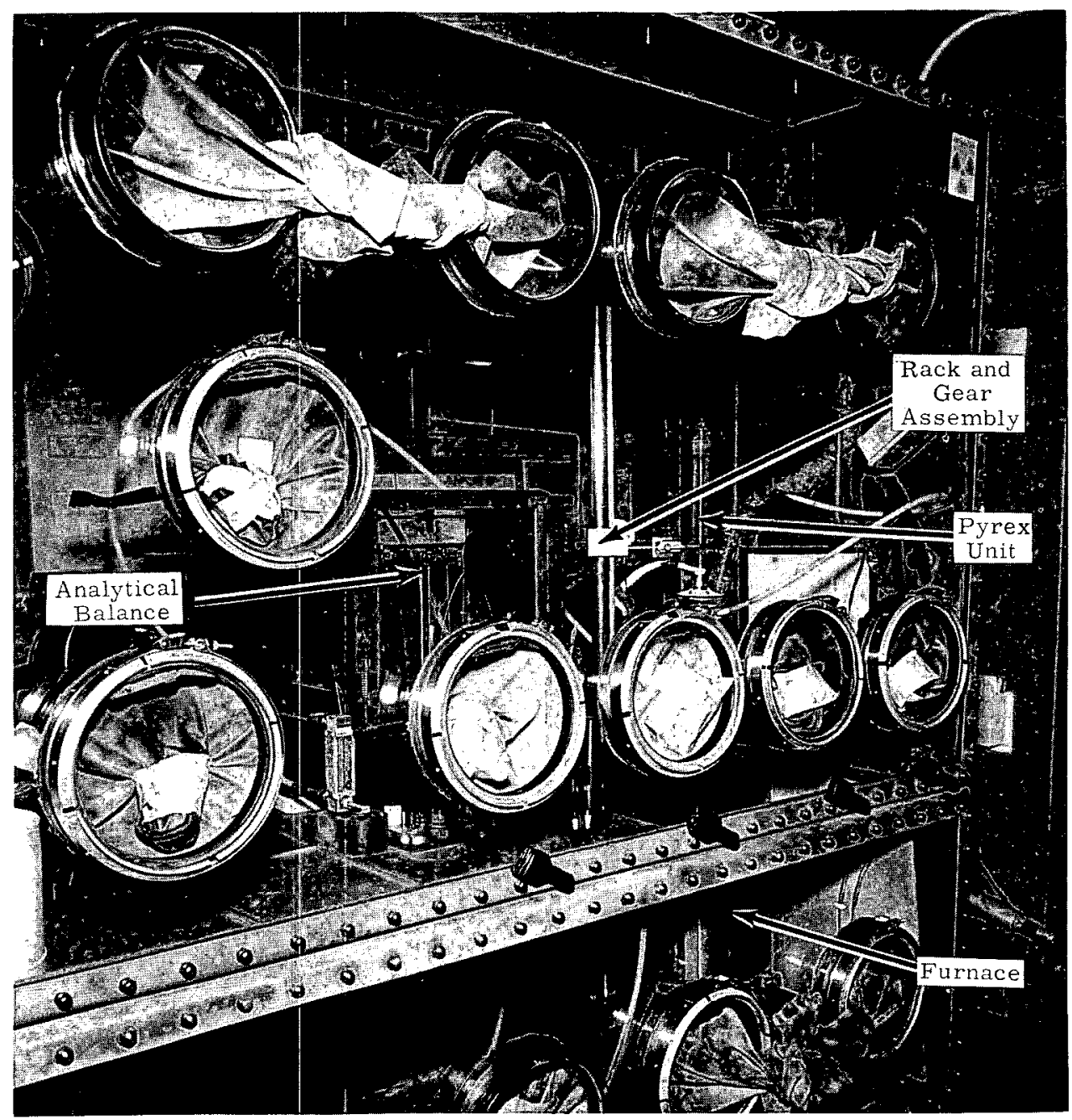

FIGURE 1

Gloved Box

\section{Balance System}

The weighing system consisted of a quartz helix spring and a linear variable differential transformer (LVDT). An LVDT is an electromechanical transducer that produces an electrical output that is proportional to the displacement of a movable iron core. A rod-shaped magnetic core is positioned axially inside the cylindrical transducer coil and provides a path for magnetic flux linking the coils. 
A quartz helical spring and the iron core (armature) of the LVDT (transducer coil) weresuspended from a ground glass stopper. The extension of the spring causes the core to move; the amount of movement is proportional to the load applied. To protect the iron core from the corrosive atmosphere, it was enclosed in Pyrex. This operation was very critical, since heating the core will cause a change in its magnetic properties. Quartz links were used below the core to connect it to a quartz sample boat. Platinum could not be used because it is readily attacked by phosgene. To reduce the possibility of vibrational nodes in the suspension chain, the quartz links were constructed of various lengths. The spring did not require a thermostat to prevent elongation with respect to an increase in temperature, since the purge gas and heat reflecting material on the baffles prevented any excess heating of the spring. The balance mechanism as shown in Figure 2 was then suspended inside the thermobalance glassware as shown in Figures 3 and 4.

As shown in Figure 3, the thermobalance glassware was composed of two portions: the Pyrex unit which is above the heating zone, and the quartz reaction tube in the heating zone. The two units are connected by a $65 / 40$ ball and socket of their respective materials.

The Pyrex unit consists of three sections. The upper portion houses the quartz helix spring $(12 \mathrm{~g}$ load capacity, $6 \mathrm{~cm}$ extensions, $0.005 \mathrm{~mm} / \mathrm{mg}$ extension) which responds to the change in sample weight. The center portion surrounded the iron core and was itself surrounded by the LVDT (linear range 0.100 in.). There was also an adjustable platform for positioning the transducer coil. The base of the platform rests on the shoulder of the lower portion of the Pyrex tube. This lower portion has an argon purge inlet near the top and four baffles below it to keep the sensing unit free of corrosive atmosphere. This system prevented any reacting gas from contacting the balance mechanism. 


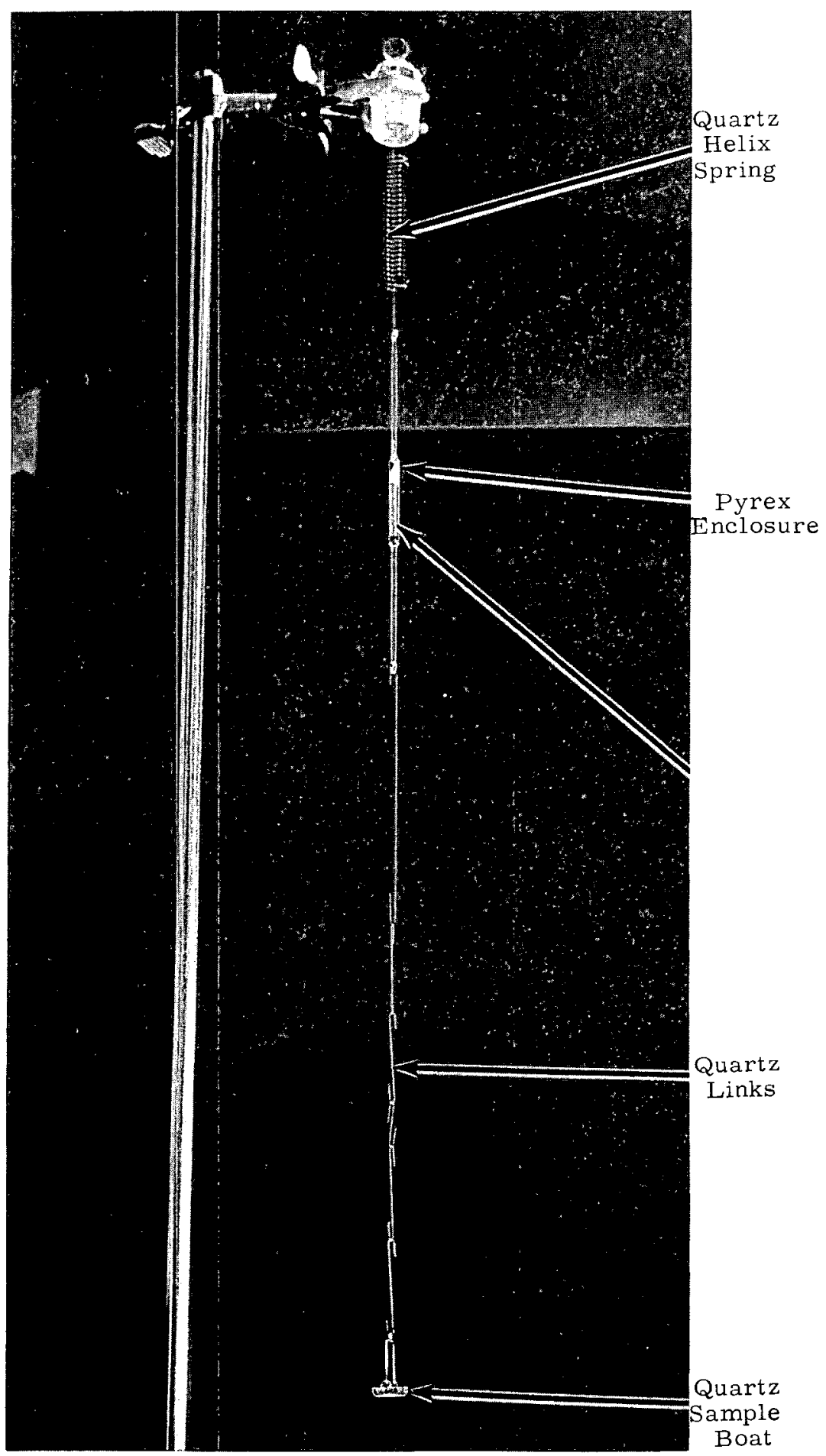

FIGURE 2

Balance Mechanism 


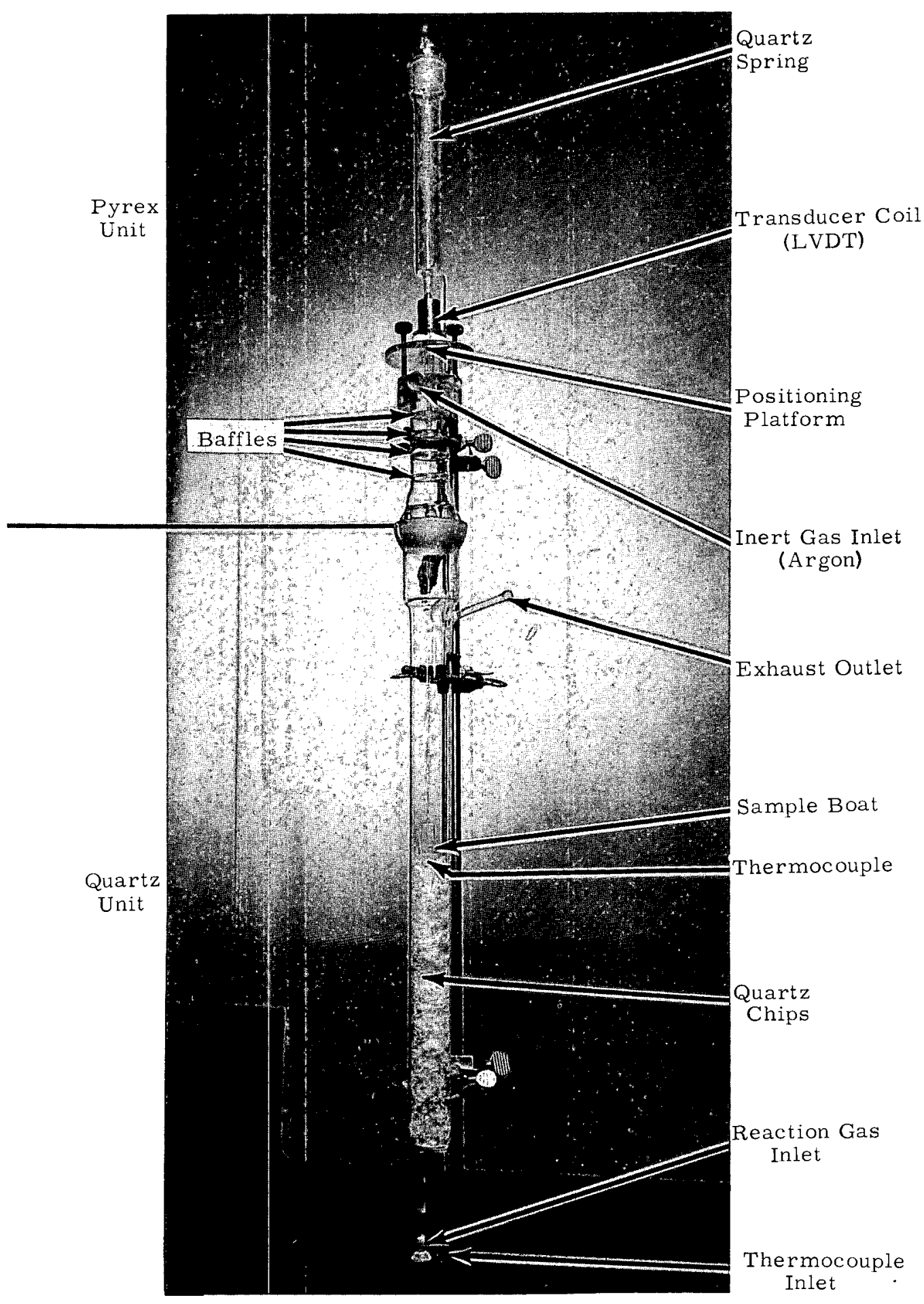

FIGURE 3

Thermobalance Glassware 


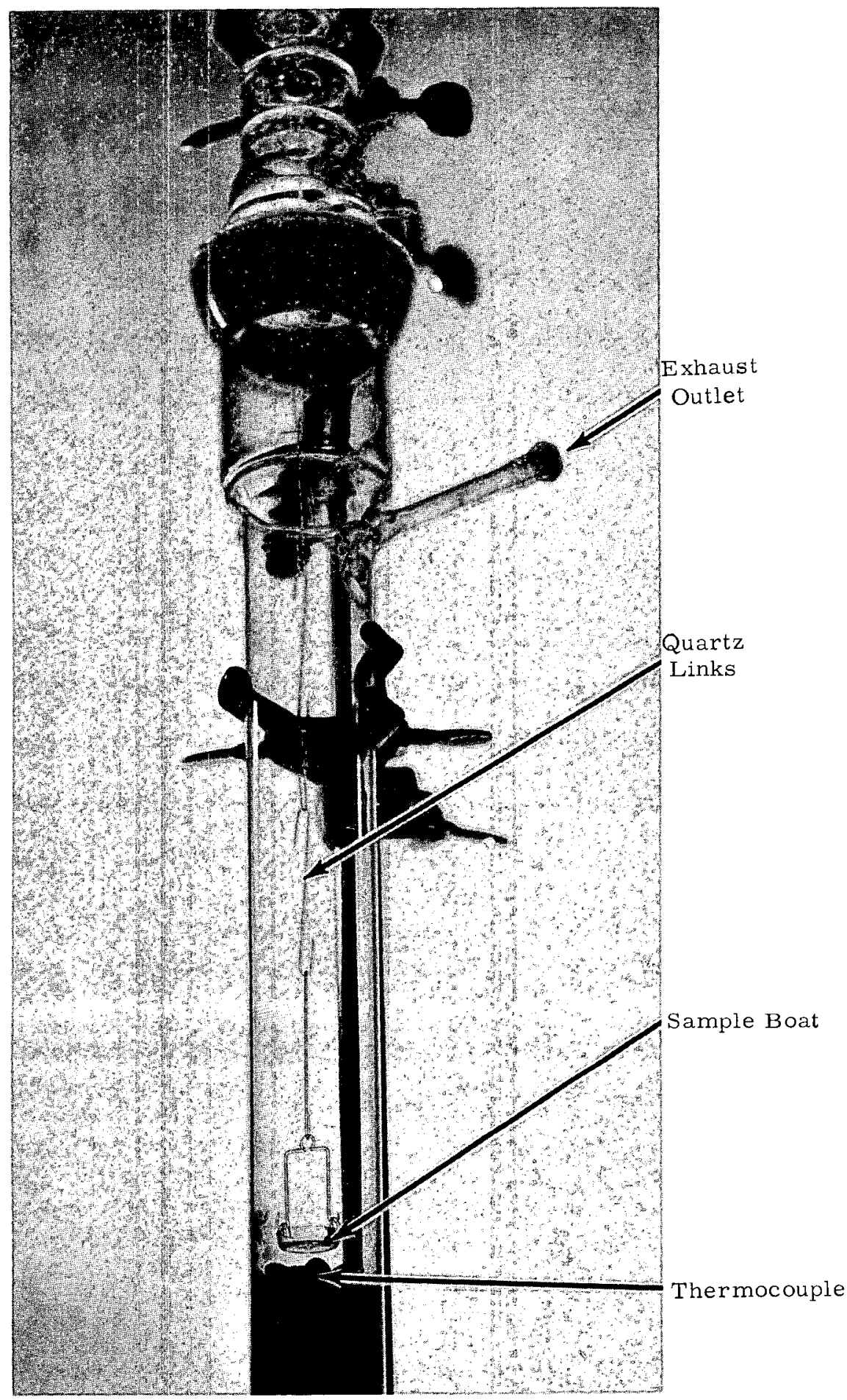

FIGURE 4

Quartz Furnace Tube and Sample Boat 
The quartz unit was half filled with quartz chips to preheat the entering gas and diffuse the gas to prevent streaming. The two small tubes at the bottom of the reaction tube protrude from the bottom of the furance. One contains a ceramic-covered $\mathrm{Pt} / \mathrm{Pt}-10 \% \mathrm{Rh}$ thermocouple which protrudes approximately $\frac{1}{2} \mathrm{in}$. above the quartz chips. The other is the reaction gas inlet. Near the top of the reaction tube is the exhaust outlet for both the inert and reacting gases. Figure 4 shows the quartz unit, including the thin quartz sheath.

The Pyrex unit was raised and lowered with a stainless steel rack and gear assembly. This was done because existing materials already in the glove box were used to construct the instrument. The entire unit is shock-mounted with lead bricks.

Heating and Control System

A low voltage, high amperage tube furnace was used to heat the sample. The furnace temperature was controlled with a time-proportional controller. The furnace was supplied with a sensing thermocouple, and a motor-driven programmer was connected to the controller via a step-down transformer. This arrangement is shown in the lower half of Figure 5, except for the transformer which was mounted on the end of the glove box.

The sample temperature was measured by the thermocouple in the quartz reaction tube and was recorded. The thermocouples in the quartz reaction tube and in the furnace were made of $\mathrm{Pt} / \mathrm{Pt}-10 \% \mathrm{Rh}$.

In this system, the controller was actually controlling a $20 \mathrm{amp}$ relay which is connected to the transformer via the programmer. This heavy relay caused transients to be introduced in the weight change sensing system. Although the effect was not too serious (it could be corrected), the equipment became a maintenance problem and is being replaced by a silicon-controlled rectifier power controller and a cam-driven programmer. 


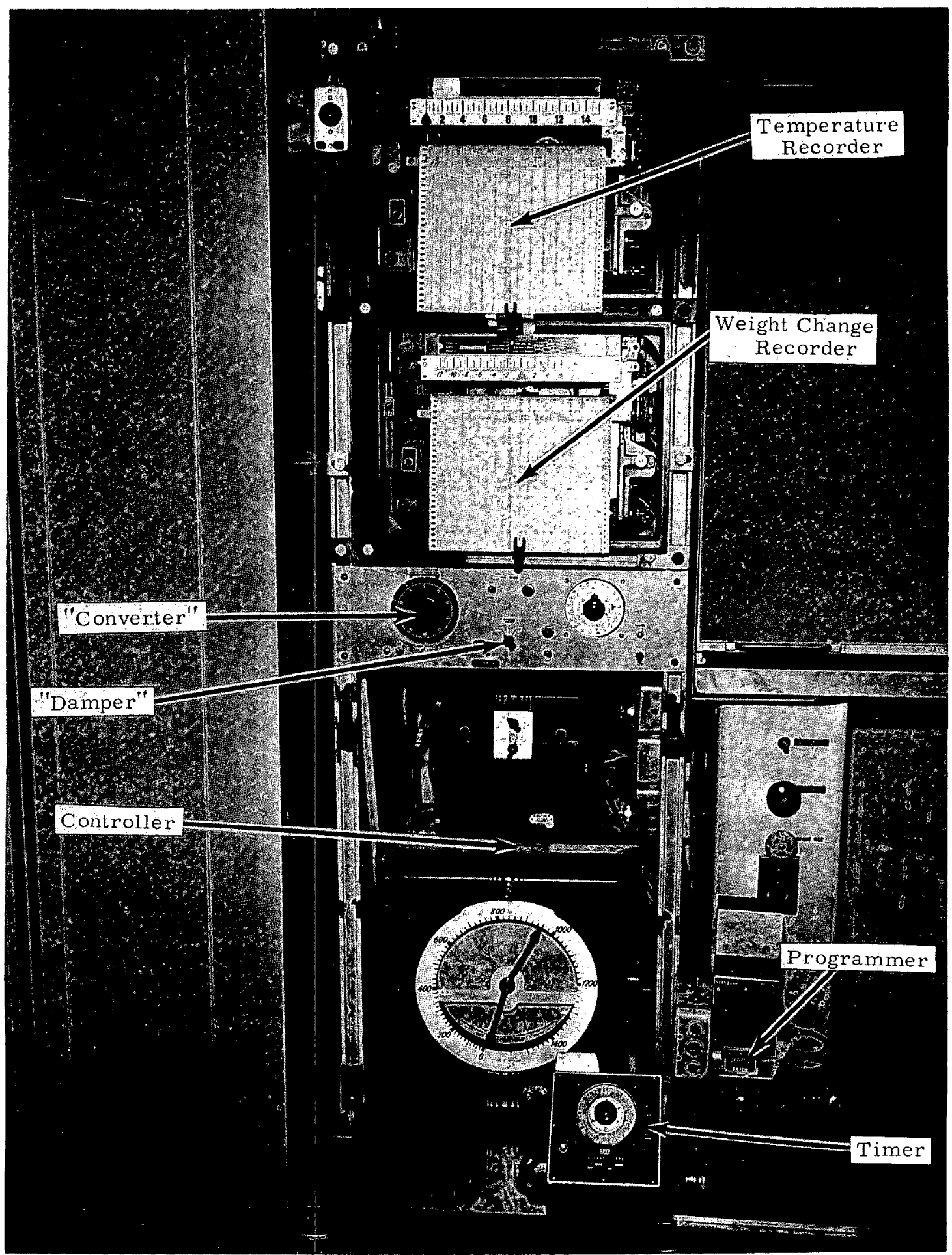

FIGURE 5

Heating and Control System Instrumentation 


\section{$\underline{\text { Recording System }}$}

If the sample gains or loses weight, the corresponding elongation or contraction of the quartz helix spring moves the iron core with respect to the transducer coil. This movement causes an electrical output that is directly proportional to the weight change. With the iron core in the center of the coil, there is no signal; but if it moves in either direction, a signal is generated, allowing the measurement of both weight gains and weight losses.

The electronic system was composed of the transducer, a converter, a damper, a controller, a programmer, and recorders. The converter reduced 110 to $6.3 \mathrm{Vac}$ and converted the alternating current output from the transducer coil to direct current for a millivolt recorder. Since there was no mechanical damper in the system, it was desirable to electronically dampen (using capacitors) any eccentricities or oscillations. The recorder used was a standard -12 to 0 to $+12 \mathrm{mv}$ recording potentiometer that was calibrated with a linear scale in milligrams (see Figure 5). A timer was used to operate the instrument a predetermined time.

$\underline{\text { Gases }}$

Argon was used as the inert gas for purging the Pyrex unit and the furnace tube. Phosgene, which was obtained in $10 \mathrm{lb}$ cylinders, was placed inside a Lucite enclosure in the fume hood adjacent to the glove box. The gas was transferred from the hood to the glove box via a valve and flow meter. Figure 6 shows the valve, flow meter, and connections inside the Lucite enclosures. The enclosures were kept under slightly negative pressures. Since phosgene is denser than air, the vacuum was applied at the bottom of these enclosures.

After the $\mathrm{PuO}_{2}$ was chlorinated, it was converted back to the oxide with air. It was not necessary to accurately meter the air, so a simple flow indicator was used. All the gases were transported by flexible polyethylene tubing inside the glove box; stainless steel tubing was used outside. 
Hood

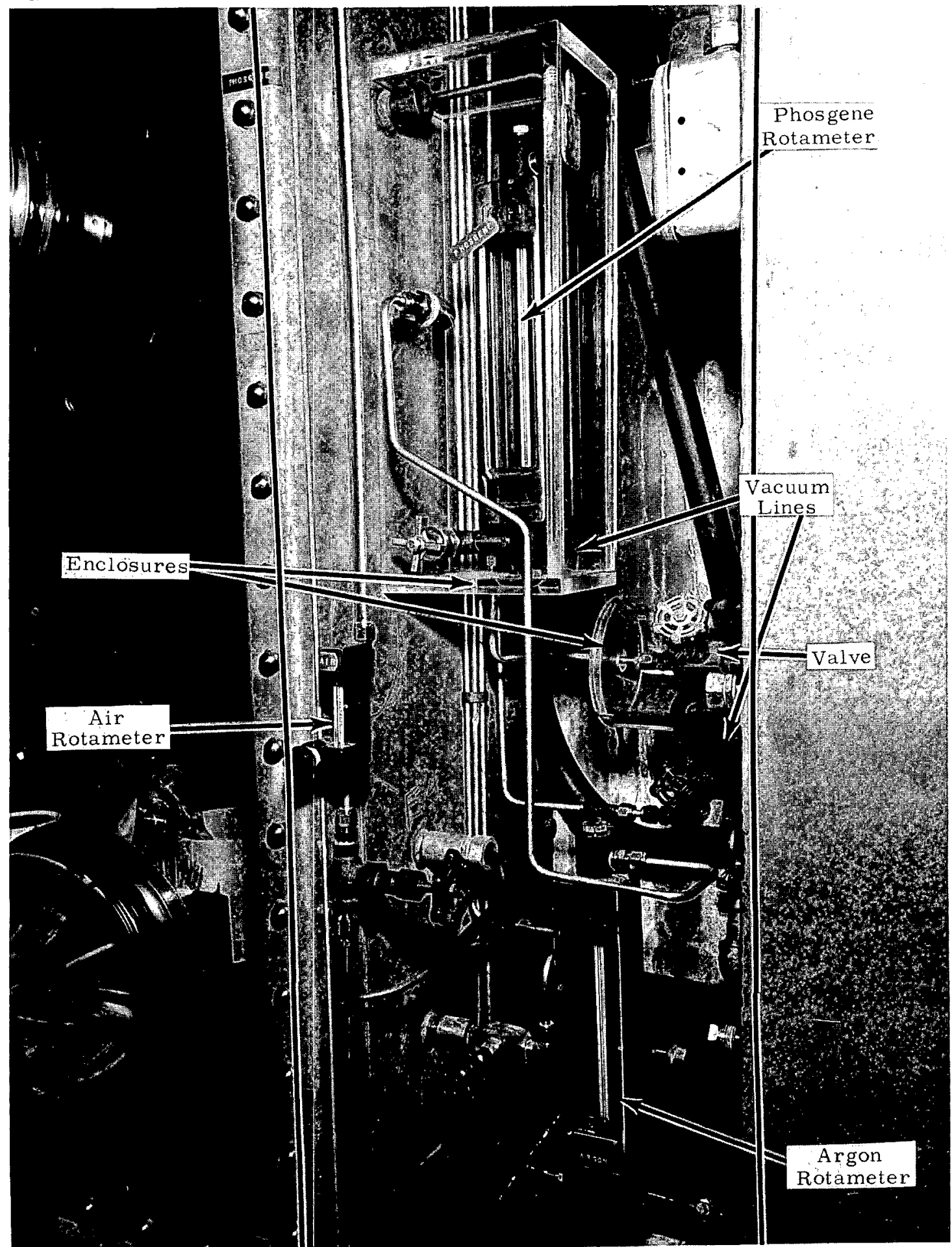

FIGURE 6

Gas Handling System 
Exhaust Gases

The composition of the gas resulting when a stream of phosgene is heated above $500 \mathrm{C}$ has been reported by Lust ${ }^{(4)}$ to be phosgene, carbon monoxide, chlorine, and hydrogen chloride. He reports that appreciable dissociation of phosgene was not observed below $500 \mathrm{C}$, but when $\mathrm{PuO}_{2}$ was present, dissociation was observed at all temperatures investigated. The exhaust gases from the chlorination of $\mathrm{PuO}_{2}$ at $425 \mathrm{C}$, after filtering and cooling were shown to be phosgene, carbon dioxide, carbon monoxide, chlorine, and hydrogen chloride. Other authors report that the dissociation of phosgene starts at $300 \mathrm{C}$, and is complete at $800 \mathrm{C}^{(5)}$ and that phosgene is $21 \%$ dissociated at $400 \mathrm{C}$. ${ }^{(6)}$ The system could, therefore, be expected to contain phosgene, carbon monoxide, carbon dioxide, chlorine, hydrogen chloride, and volatile metallic chlorides from impurities.

Walker ${ }^{(7)}$ has shown that the system is extremely corrosive towards gold, platinum, etc. For example, he exposed samples of platinum and gold to a stream of phosgene at $500 \mathrm{C}$ and found that they were completely destroyed in less than $70 \mathrm{hr}$.

During the chlorination, solid deposits were found on the upper portion of the quartz reaction tube, ball and socket joint, and on the lower portion of the Pyrex unit. They varied in color from light yellow to dark reddish-brown; the nearer the furnace, the darker the color. Lust ${ }^{(4)}$ has previously shown that these deposits are due to impurities in the $\mathrm{PuO}_{2}$, and that surfaces kept above $325 \mathrm{C}$ showed no trace of these solids which are volatile metal chlorides.

Pressure surges due to bubbling the exhaust gas through a caustic solution decreased the sensitivity of the balance. Therefore, the exhaust gases were passed up through a continuous, gas-phase type, scrubbing tower. This apparatus was very efficient and kept the inside of the glove box almost corrosion free. 


\section{OPERATION AND PROCEDURE}

A sample was placed in the tared quartz sample boat and weighed on the analytical balance. The boat was then suspended from the quartz chain, the Pyrex unit was lowered into position, and the instrumentation was started. Although larger samples could be used, most thermograms were run using approximately $200 \mathrm{mg}$ of material. The bed depth was, therefore,

kept to less than $\frac{1}{8}$-in. and better resolution was obtained. After the system was cooled (the sample was usually cooled under an inert atmosphere), the sample boat was removed and reweighed.

$\underline{\text { Standardization }}$

The instrument was standardized with standard platinum weights, calcium carbonate, and calcium oxalate monohydrate. The weight change "breaks" agreed with both theoretical and reported values for calcium oxalate monohydrate. $(8,9,10,11)$ The standardization was begun as described above, with argon flowing at the rate of approximately $40 \mathrm{cc} / \mathrm{min}$ through the reaction gas inlet, and at least $70 \mathrm{cc} / \mathrm{min}$ through the purge gas inlet. The instrument was heated from room temperature to approximately $1050 \mathrm{C}$ at less than $3 \mathrm{C}^{\circ} / \mathrm{min}$. At this slow rate of heating, there appeared to be very little thermal lag between the furnace temperature and the sample temperature as measured by the thermocouple enclosed in the thin quartz sheath.

Two types of experiments were made at constant weight to check the pen drift with respect to temperature and time. A 200.1 $\mathrm{mg}$ quartz weight was used. A slight decrease in apparent weight was observed upon heating from room temperature to $1050 \mathrm{C}$ in approximately $5 \mathrm{hr}$. A further slight decrease was observed during the subsequent $2 \mathrm{hr}$ at $1000 \mathrm{C}$. In a different test, the instrument was raised to $500 \mathrm{C}$, the quartz weight and sample boat were inserted in the instrument, and the temperature was held for approximately $7 \mathrm{hr}$. The general trend indicated a slight weight loss with time. In both experiments, the apparent weight loss was less than $5.0 \mathrm{mg}$. The capability of the thermobalance is thus limited by a $5 \%$ maximum error in the 
determination of sample weights. It was necessary to restandardize the thermobalance and run blank checks rather frequently during the chlorination experiments, since the volatile metal chlorides sublime onto the quartz chain and increase the weight of the suspension system.

\section{Chlorination}

When a sample of $\mathrm{PuO}_{2}$ was to be chlorinated, the instrument was heated to a predetermined temperature, usually $500 \mathrm{C}$. Phosgene was allowed to flow at approximately $45 \mathrm{cc} / \mathrm{min}$ for at least $15 \mathrm{~min}$ (at least three reaction tube volumes) before the sample was introduced. The caustic scrubber was always started simultaneously with the phosgene.

The Pyrex unit was then quickly raised, the preweighed sample boat was suspended from the quartz chain, and the Pyrex unit was lowered. This was only a momentary break in the system, and since phosgene is denser than air, very little would escape from the quartz furnace tube. Of course, the phosgene was still entering the bottom of the furnace tube.

Upon completion of the chlorination reaction, the entering gas was changed to argon and a $\mathrm{PuCl}_{3}$ weight was obtained. Since $\mathrm{PuCl}_{3}$ is hygroscopic and reactive, an air weight could not be obtained. The correction on the thermogram due to different gas densities was very small. Air was then used to oxidize the $\mathrm{PuCl}_{3}$ to $\mathrm{PuO}_{2}$. The temperature of the system was raised to $1050 \mathrm{C}$, held for at least $1 \mathrm{hr}$ in air, cooled, and the sample boat was reweighed-first in argon and then on the analytical balance. The weight of the high-fired oxide was used in all the calculations. This was necessary since the starting material contained 4 to $60 \mathrm{wt} \%$ impurities.

The $1050 \mathrm{C}$ oxide material was considered to be stoichiometric $\mathrm{PuO}_{2}$. It has been reported that 1180 or $1250 \mathrm{C}^{(12,13)}$ is necessary to form the stoichiometric dioxide. Since it is generally accepted that quartz holds a constant weight to approximately $1035 \mathrm{C}$ and that devitrification occurs above this temperature, the system was usually heated no higher than $1050 \mathrm{C}$ and an occasional $1200 \mathrm{C}$. No significant weight changes were observed when several test oxides were heated from 1050 to $1200 \mathrm{C}$. 
To correct the instrument for buoyance, convection currents, and viscous drag, a thermogravimetric blank for the empty crucible containing a $200 \mathrm{mg}$ quartz weight was determined exactly as the sample was to be run. Usually the blank correction was approximately 5\%. With increasing temperature, the blanks consistently showed a weight loss.

\section{APPLICATIONS}

The following data illustrate the application of this instrument. The data shown are preliminary and are presented mainly to illustrate rather than to inform.

Effect of Temperature

A $10 \mathrm{~g}$ sample of specially-prepared $\mathrm{PuO}_{2}$ that was produced at HAPO and which was especially reactive was used as a standard. Samples of this standard were chlorinated at $25 \mathrm{C}^{\circ}$ temperature intervals between 425 and $525 \mathrm{C}$ (isothermal). The first order (with respect to $\mathrm{PuO}_{2}$ ) character of the reaction is indicated by the straight lines obtained on plotting the $\log$ of the concentration of unreacted $\mathrm{PuO}_{2}$ versus time as shown in Figure 7. Approximately the same rate of chlorination is achieved at temperatures from 450 to $525 \mathrm{C}$, with $500 \mathrm{C}$ giving a slightly greater rate. The volatile material by actual weight was approximately $5.3 \%$.

Figure 8 shows a plot of the logarithm of the reaction rate constants versus the reciprocal temperature in Kelvin. From the slope of this line, the energy of activation $\left(E^{*}\right)$ was calculated to be $17.2 \mathrm{kcal}$.

Effect of Particle Size

A sample of relatively unreactive $\mathrm{PuO}_{2}$ which had been calcined at $300 \mathrm{C}$ for $14 \mathrm{hr}$ was analyzed for particle size. Samples of the original material which contained $80 \mathrm{wt} \% 105$ to $250 \mathrm{micron}$ and $10 \mathrm{wt} \% 49$ to 105 micron particles; a 49 to 105 micron fraction of the original material, and a less than 49 micron fraction were chlorinated. As shown in Figure 9, the smaller the particle size, the greater the reaction rate. 


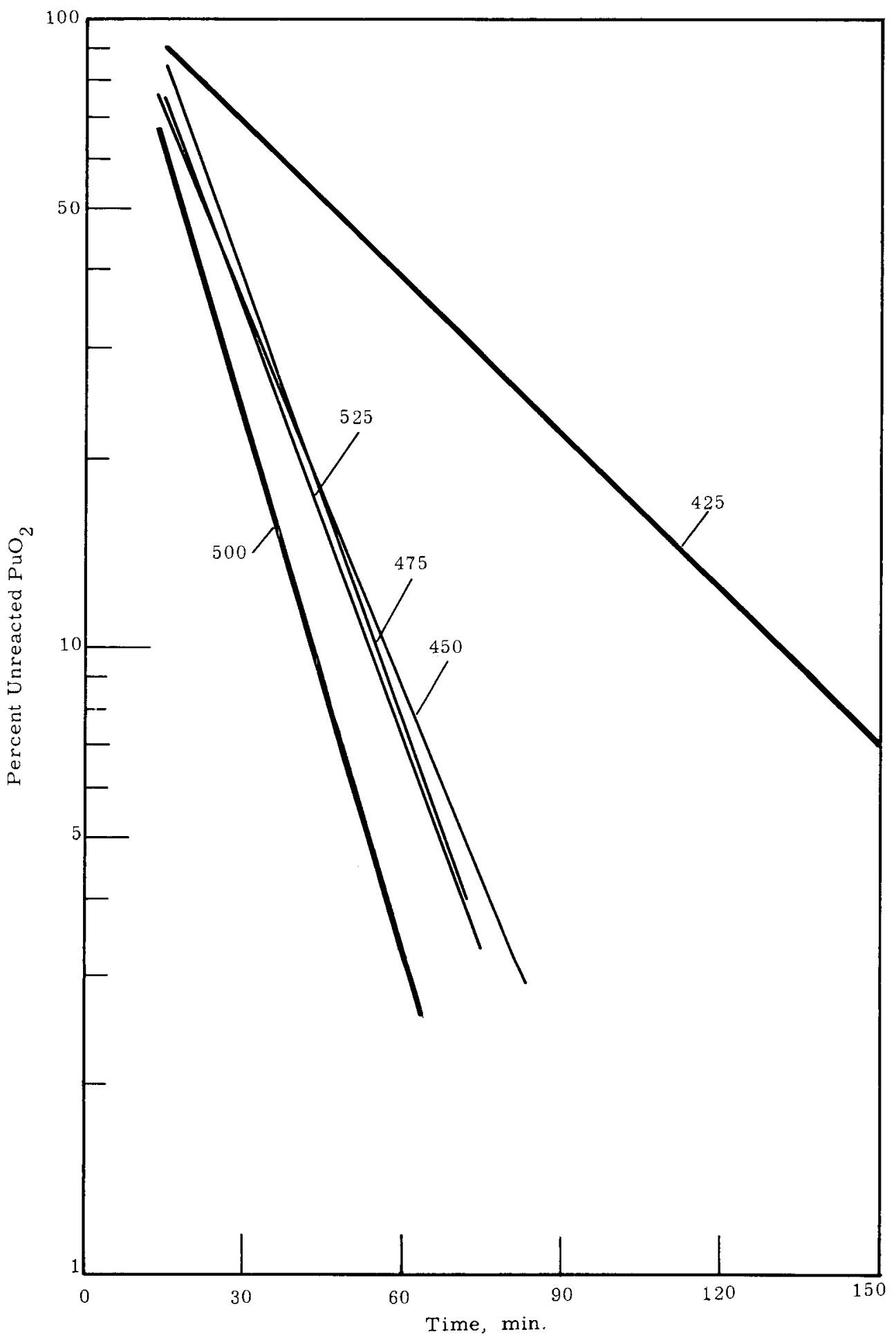

FIGURE 7

Effect of Temperature on the Chlorination Rate 


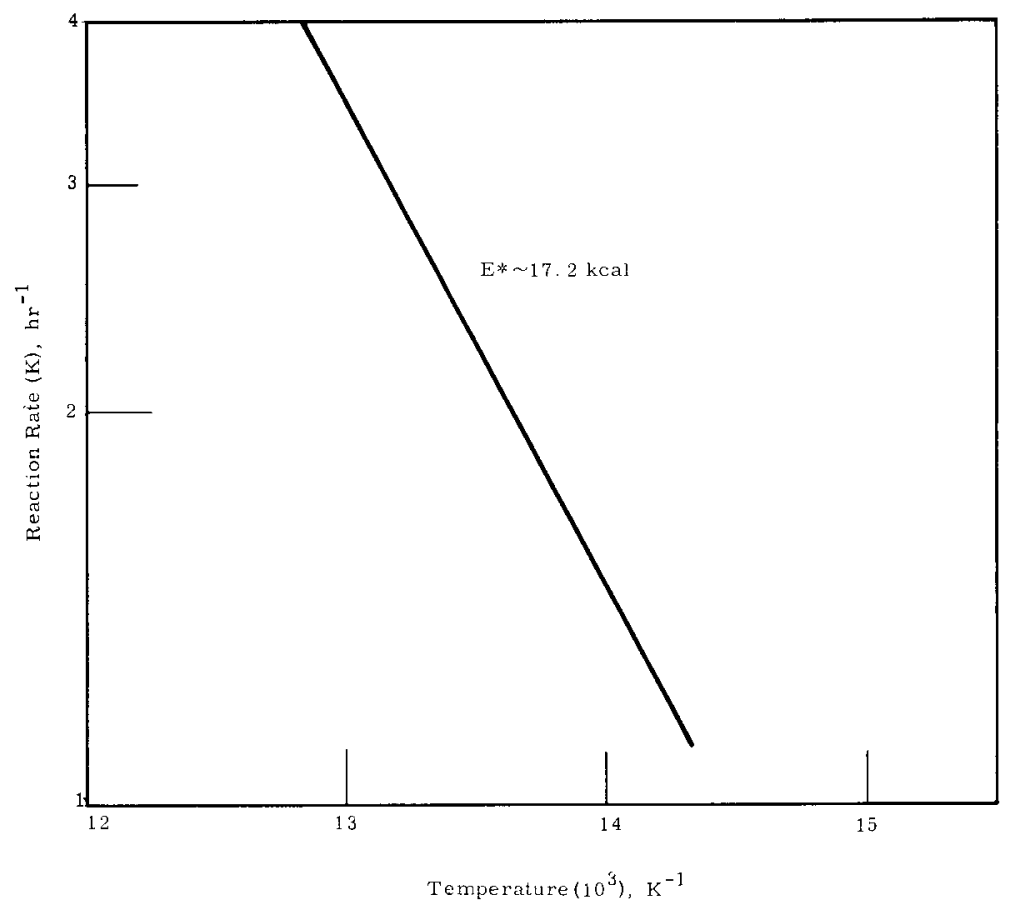

FIGURE 8

Energy of Activation

(Arrhenius)

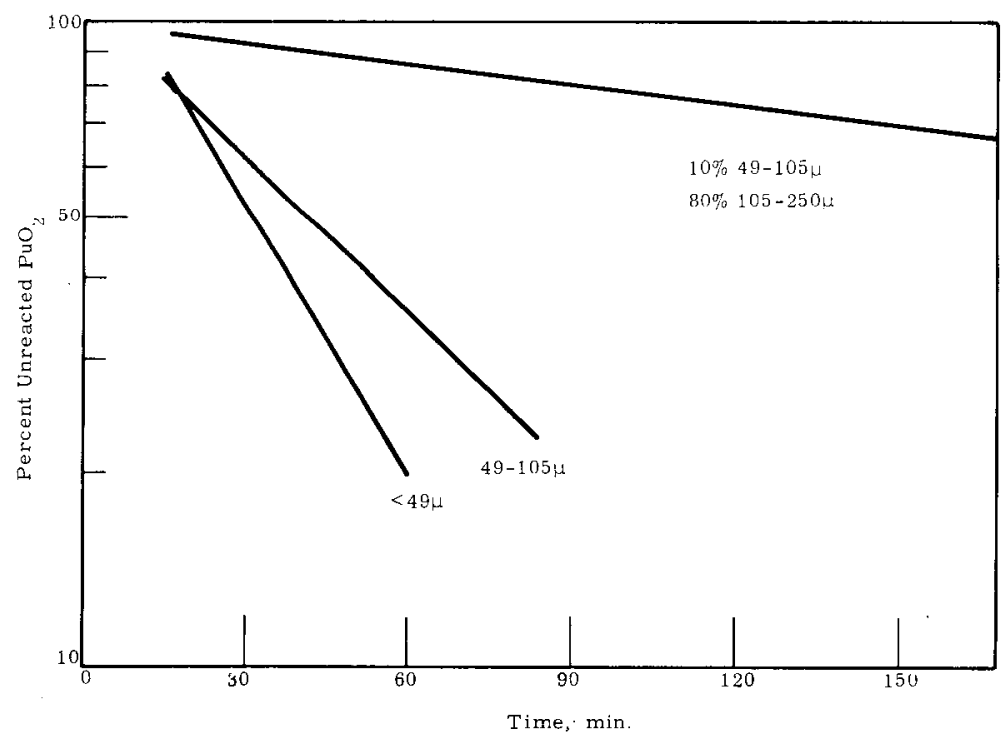

FIGURE 9

Effect of Particle Size on the Chlorination Rate 
Effect of Calcination Time

A sample of $\mathrm{PuO}_{2}$ was calcined at $300 \mathrm{C}$ for a prolonged time and small aliquots were taken after $0.1,2.0,6.0$, and $20 \mathrm{hr}$. These samples were chlorinated in the thermobalance at $500 \mathrm{C}$. The results, shown in Figure 10, indicate that a short calcination time is desirable.

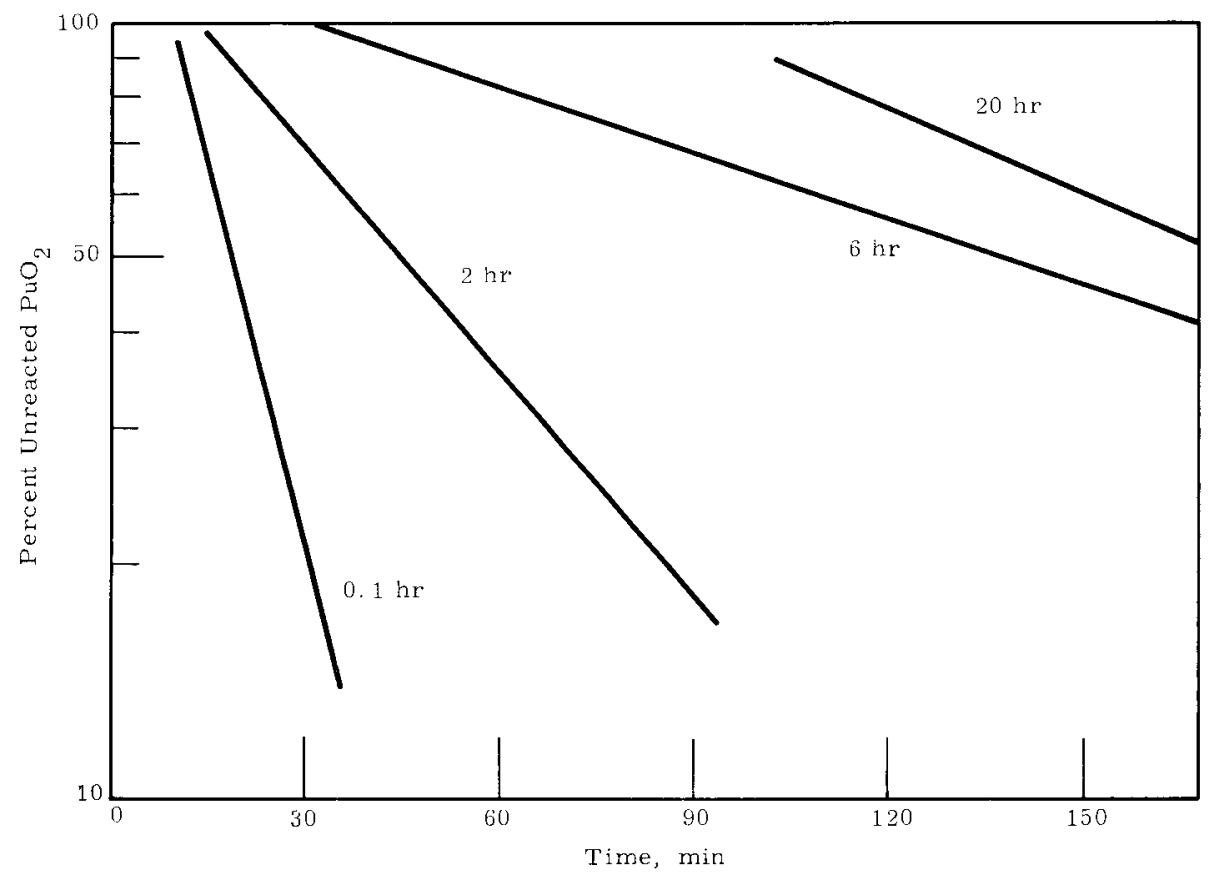

FIGURE 10

Effect of Plutonium Dioxide Calcination Time (300 C) on the Chlorination Rate

The reaction rate is decreased as the calcination time is increased.

The longer exposure causes a gradual perfection in the highly distorted and impurity-containing $\mathrm{PuO}_{2}$ lattice obtained by shorter calcination times.

Effect of Additives

$\mathrm{PuO}_{2}$ prepared by direct calcination from the nitrate was found to chlorinate slowly and incompletely. It has been assumed that this low reactivity is due, at least in part, to the relative impermeability of the 
$\mathrm{PuO}_{2}$ particles. This low reactivity has also been attributed to the high degree of crystallinity and the lack of impurities in the oxide.

Activating additives were investigated in an effort to obtain more reactive direct calcination oxides. They would aid by causing an open structure whereby gas access to the center of the particle is increased and by inhibiting crystal growth and perfection. Both oxalic acid and ammonium sulfate were tried and it was found that the latter was a more satisfactory activating agent when used in massive quantities. Figure 11 shows the effect of sulfate and oxalate additions for several mole ratios of plutonium to additive. The additive has been shown to be quantitatively removed during the chlorination.

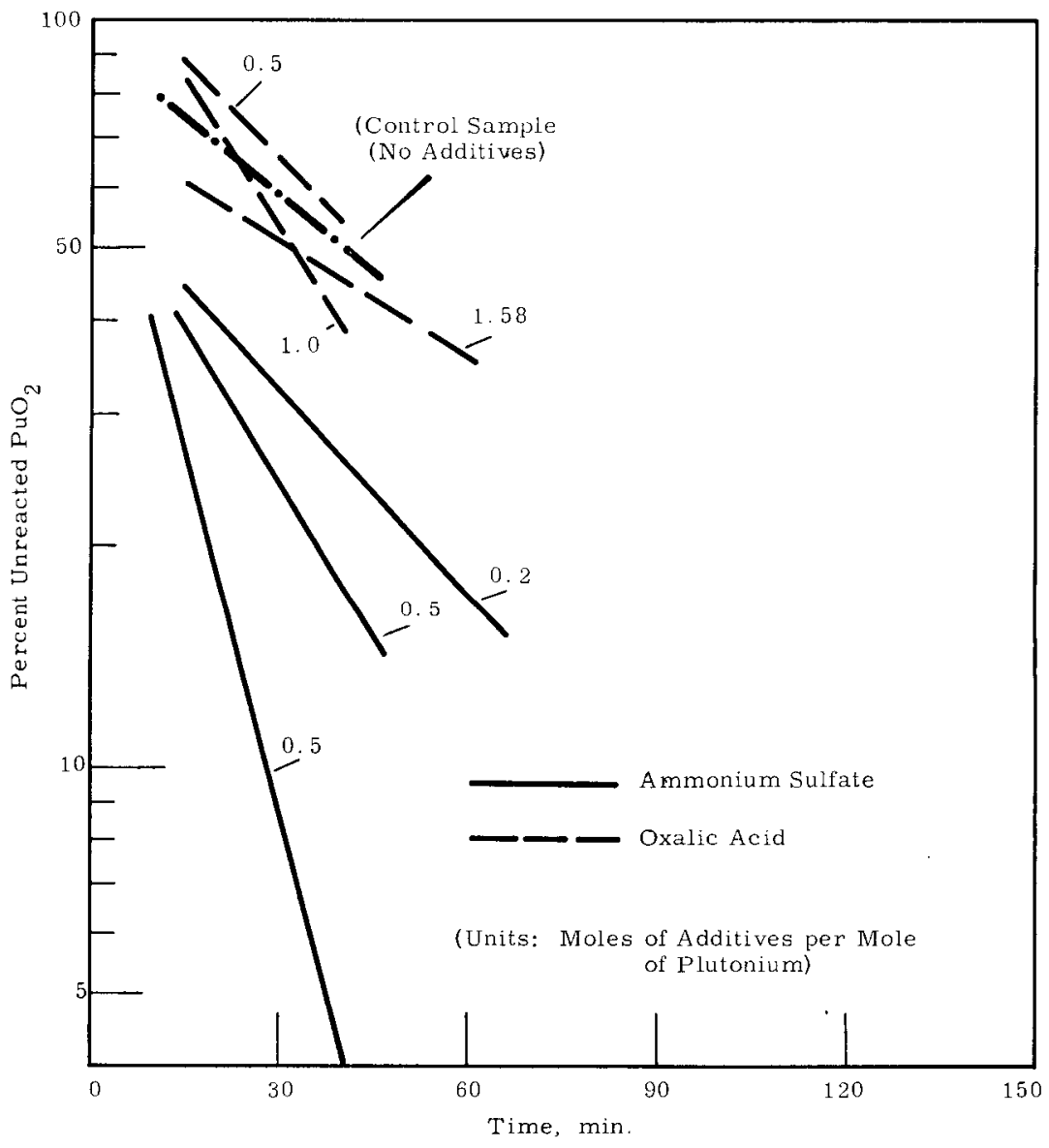

FIGURE 11

Effect of Additives on the Chlorination Rate 


\section{ACKNOWLEDGEMENTS}

The author is indebted to K. M. Harmon and R. A. Schneider for their helpful advice and support during the course of this work; to the glassblower, W. R. Watts, who built the instrument; and to M. J. Rasmussen, G. L. Stiffler, and F. D. Fisher who prepared and supplied all the samples.

\section{REFERENCES}

1. F. D. Fisher. Unpublished Data, October, 1963. (Reactivity of Plutonium Dioxide Prepared by Direct Calcination of Nitrate Solution.)

2. M. J. Rasmussen and H. H. Hopkins, Jr. "Preparing Plutonium Metal Via the Chloride Process," Ind. Eng. Chem., vol. 53, pp. 453-457. 1961 .

3. M. J. Rasmussen, G. L. Stiffler, and H. H. Hopkins, Jro Parameters in the Conversion of Plutonium Nitrate to Plutonium Trichloride by a Direct Calcination-Fluid Bed Chlorination Process. $\mathrm{HW}-69738$. May 31, 1961.

4. L. F. Lust. The Analysis of Exhaust Products in the Chlorination of Plutonium Oxide with Phosgene. HW-59749。 March 2, 1959.

5. G. M. Dyson. "Phosgene," Chem.Rev., vol.4, p. 123. 1927.

6. C. F. Prutton and S. H. Maron. Fundamental Principles of Physical Chemistry, The MacMillan Company, New York, 1958. 3rd ed., pp. 341-350.

7. W. L. Walker. Corrosion of Various Metals and Alloys by Phosgene, Hydrogen Chloride, and Carbon Tetrachloride at 400 to $600 \mathrm{C}$.

HW-68738. April 1, 1961

8. Clement Duval. Inorganic Thermogravimetric Analysis, Elsevier Publishing Company, 52 Vanderbilt Ave., New York. 1962.

9. Clement Duval. "Continuous Weighing in Analytical Chemistry," Anal. Chem. vol.23, pp. 1271-1286, 1951.

10. E. S. Freeman and B. Carroll. "The Application of Thermoanalytical Techniques to Reaction Kinetics. The Thermogravimetric Evaluation of the Kinetics of the Decomposition of Calcium Oxalate Monohydrate.' J. Phys. Chem. vol. 62, pp. 394-397. 1958.

11. E. L. Simons and A. E. Newkird. New Studies on Calcium Oxalate Monohydrate: A Guide to the Interpretation of the Thermogravimetric Measurements. Report Number 63-RL-3263C. March, 1963.

12. G. R. Waterbury, R. M. Douglass, and C. F. Metz. "Thermogravimetric Behavior of Plutonium Metal, Nitrate, Sulfate, and Oxalate, ${ }^{18}$ Anal.Chem. vol. 33, pp. 1018-1023. 1961.

13. J. L. Drummond. The Gravimetric Determination of Plutonium as Oxide at $1250 \mathrm{C}$. IGO-AM-W-64。 December 18, 1956. 


\section{INTERNAL DISTRIBUTION}

Copy Number

$\begin{array}{ll}1 & \text { O. F. Beaulieu } \\ 2 & \text { H. L. Brandt } \\ 3 & \text { J. S. Buckingham } \\ 4 & \text { M. H. Campbell } \\ 5 & \text { E. W. Christopherson } \\ 6 & \text { M. H. Curtis } \\ 7 & \text { C. L. Downey } \\ 8 & \text { F. D. Fisher } \\ 9 & \text { W. S. Frank } \\ 10 & \text { H. T. Fullam } \\ 11 & \text { W. J. Gartin } \\ 12 & \text { K. M. Harmon } \\ 13 & \text { H. H. Hopkins, Jr. } \\ 14 & \text { J. W. Jordan } \\ 15 & \text { L. M. Knights } \\ 16 & \text { R. J. Kofoed, Jr. } \\ 17 & \text { M. C. Lambert } \\ 18 & \text { C. W. Pollock } \\ 19 & \text { M. J. Rasmussen } \\ 20 & \text { R. A. Schneider } \\ 21 & \text { F. A. Scott } \\ 22-47 & \text { R. J. Sorenson } \\ 48 & \text { M. J. Szulinski } \\ 49 & \text { A. J. Waligura } \\ 50 & \text { N. S. Wing } \\ 51 & \text { Technical Publications } \\ 52 & \text { Record Center } \\ 53 & \text { 300 File Copy } \\ 54-58 & \text { Extra } \\ & \end{array}$

\section{EXTERNAL DISTRIBUTION (Special)}

Number of Copies 
Standard Distribution

ABERDEEN PROVING GROUND

AEROJET.GENERAL CORPORATION

AEROJET-GENERAL NUCLEONICS

AERONAUTICAL SYSTEMS DIVISION

AIR FORCE CAMBRIDGE RESEARCH LABORATORIES

AIR FORCE INSTITUTE OF TECHNOLOGY

״AIR ForCE wEAPONS LABORATORY

ALBUQUERQUE OPERATIONS OFFICE

ALLIS-CHALMERS MANUFACTURING COMPANY

ALLIS-CHALMERS MANUFACTURING COMPANY, WASHINGTON

ALLISON DIVISION-GMC

ARGONNE CANCER RESEARCH HOSPITAL

ARGONNE NATIONAL LABORATORY

ARMED FORCES RADIOBIOLOGY RESEARCH INSTITUTE

ARMY CHEMICAL CENTER

ARMY ENGINEER RESEARCH AND DEYELOP. MENT LABORATORIES

ARMY ENVIRONMENTAL HYGIENE AGENCY

ARMY MISSILE COMMAND

ARMY RESEARCH OFFICE, DURHAM

ARMY SIGNAL RESEARCH AND DEVELOPMENT LABORATORY

ATOMIC BOMB CASUALTY COMMISSION

AEC SCIENTIFIC REPRESENTATIVE, FRANCE

AEC SCIENTIFIC REPRESENTATIVE, JAPAN

ATOMIC ENERGY COMMISSION, WASHINGTON

ATOMIC ENERGY OF CANADA LIMITED

ATOMICS INTERNATIONAL

AYCO CORPORATION

BABCOCK AND WILCOX COMPANY

BATTELLE MEMORIAL INSTITUTE

BERYLLIUM CORPORATION

BORDEN CHEMICAL COMPANY

BROOKHAVEN NATIONAL LAB ORATORY
Ptd.
Standard Distribution

BUREAU OF MEDICINE AND SURGERY

BUREAU OF MINES, ALBANY

BUREAU OF MINES, SALT LAKE CITY

BUREAU OF SHIPS (CODE 1500)

CHANCE YOUGHT CORPORATION

CHICAGO PATENT GROUP

COLUMBIA UNIVERSITY (CROPPER)

COMBUSTION ENGINEERING, INC. COMBUSTION ENGINEERING, INC. (NRD)

COMMITTEE ON THE EFFECTS OF ATOMIC RADIATION

DEFENCE RESEARCH MEMBER

DENYER RESEARCH INSTITUTE

DIVISION OF RAW MATERIALS, WASHINGTON

DOW CHEMICAL COMPANY, ROCKY FLATS

DU PONT COMPANY, A!KEN

DU PONT COMPANY, WILMINGTON

EDGERTON, GERMESHAUSEN AND GRIER, INC., GOLETA

EDGERTON, GERMESHAUSEN AND GRIER, INC., LAS YEGAS

FRANKFORD ARSENAL

FUNDAMENTAL METHODS ASSOCIATION

GENERAL ATOMIC DIVISION

GENERAL DYNAMICS/FORT WORTH

GENERAL ELECTRIC COMPANY, CINCINNATI

GENERAL ELECTRIC COMPANY, SAN JOSE

GENERAL TELEPHONE AND ELECTRONICS LABORATORIES, INC.

GOODYEAR ATOMIC CORPORATION

GRAND JUNCTION OFFICE

HAZL ETON NUCLEAR SCIENCE CORPORATION

HUGHES AIRCRAFT COMPANY

IOWA STATE UNIVERSITY

JET PROPULSION LABORATORY

KNOLLS ATOMIC POWER LABORATORY 
Ptd.

2

1

1

1

1

1

1

1

2

$\mathbf{1}$

1
Standard Distribution

LOS ALAMOS SCIENTIFIC LABORATORY

MALLINCKRODT CHEMICAL WORKS

MARITIME ADMINISTRATION

MARTIN-MARIETTA CORPORATION

MASSACHUSETTS INSTITUTE OF TECHNOLOGY

MONSANTO CHEMICAL COMPANY

MOUND LABORATORY

NASA LEWIS RESEARCH CENTER

NASA SCIENTIFIC AND TECHNICAL INFORMATION FACILITY

NATIONAL BUREAU OF STANDARDS

NATIONAL BUREAU OF STANDARDS (LIBRARY)

NATIONAL INSTITUTES OF HEALTH

NATIONAL LEAD COMPANY OF OHIO

NAVAL HOSPITAL

NAVAL MEDICAL RESEARCH INSTITUTE

NAYAL POSTGRADUATE SCHOOL

NAYAL RADIOLOGICAL DEFENSE LABORATORY

NAVAL RESEARCH LABORATORY

NEW BRUNSWICK AREA OFFICE

NEW YORK OPERATIONS OFFICE

NUCLEAR MATERIALS AND EQUIPMENT CORPORATION

NUCLEAR METALS, INC.

OFFICE OF ASSISTANT GENERAL COUNSEL FOR PATENTS (AEC)

OFFICE OF NAYAL RESEARCH

OFFICE OF NAYAL RESEARCH (CODE 422)

OFFICE OF THE CHIEF OF RESEARCH AND DEVELOPMENT

OFFICE OF THE SURGEON GENERAL

ORDNANCE MATERIALS RESEARCH OFFICE

ORDNANCE TANK-AUTOMOTIVE COMMAND

PHILLIPS PETROLEUM COMPANY (NRTS)

POWER REACTOR DEVELOPMENT COMPANY

PRATT AND WHITNEY AIRCRAFT DIVISION

PRINCETON UNIVERSITY (WHITE)
Ptd.
Standard Distribution

PUBLIC HEALTH SERVICE

PUBLIC HEALTH SERVICE, CINCINNATI

PUBLIC HEALTH SERVICE, LAS VEGAS

PUBLIC HEALTH SERVICE, MONTGOMERY

PURDUE UNIVERSITY

RADIATION APPLICATIONS, INC.

RAND CORPORATION

REYNOLDS ELECTRICAL AND ENGINEERING COMPANY, INC.

SANDIA CORPORATION, ALBUQUERQUE

SANDIA CORPORATION, LIVERMORE

TECHNICAL RESEARCH GROUP

TRACERLAB, INC., RICHMOND

UNION CARBIDE NUCLEAR COMPANY (ORGDP)

UNION CARBIDE NUCLEAR COMPANY (ORNL)

UNION CARBIDE NUCLEAR COMPANY (ORNL$Y-12)$

UNION CARBIDE NUCLEAR COMPANY (PADUCAH PLANT)

UNITED NUCLEAR CORPORATION (NDA)

U. S. GEOLOGICAL SURYEY, DENYER

U. S. GEOLOGICAL SURYEY, MENLO PARK

U. S. GEOLOGICAL SURVEY, NAYAL WEAPONS PLANT

U. S. GEOLOGICAL SURYEY, WASHINGTON

U. S. GEOLOGICAL SURVEY, WR DIYISION

U. S. PATENT OFFICE

UNIVERSITY OF CALIFORNIA, BERKELEY

UNIVERSITY OF CALIFORNIA, LIVERMORE

UNIVERSITY OF CALIFORNIA, LOS ANGELES

UNIVERSITY OF HAWAII

UNIVERSITY OF PUERTO RICO

UNIVERSITY OF ROCHESTER

UNIVERSITY OF UTAH

UNIVERSITY OF WASHINGTON

WALTER REED ARMY MEDICAL CENTER

WATERTOWN ARSENAL 
Ptd.

Standard Distribution

WESTINGHOUSE BETTIS ATOMIC POWER LABORATORY

WESTINGHOUSE ELECTRIC CORPORATION

WESTINGHOUSE ELECTRIC CORPORATION (NASA)

YANKEE ATOMIC ELECTRIC COMPANY

YANKEE ATOMIC ELECTRIC COMPANY

Pid.

325

$75+$

Standard Distribution

DIVISION OF TECHNICAL INFORMATION EXTENSION

OFFICE OF TECHNICAL SERVICES, WASHINGTON

*New listing or change in old listing.

tThese copies should be shipped directly to the Office of Technical Services, Department of Commerce, Washington 25, D. C. 